\title{
Moses Judah Folkman
}

\author{
Father of angiogenesis
}

Judah Folkman spent his life in dogged pursuit of a cure for cancer. For most of his career he was ridiculed and called a charlatan. But his discoveries were eventually hailed world wide and launched a new field of study: angiogenesis. Over 1000 laboratories are now studying angiogenesis, and more than $1.2 \mathrm{~m}$ patients are taking antiangiogenic drugs for cancer and other diseases.

Folkman entered Harvard Medical School at the age of 19. In 1961 he was drafted into military service aboard a naval vessel. He was given the task of finding out whether blood could be dried and reconstituted. To test the experimental blood, Folkman bathed a cultured rabbit thyroid in the blood. The gland thrived. But Folkman went one step further, he wanted to see if the blood could support new growth, so he injected the thyroid with cancer cells, the fastest growing cells he could think of. What he observed

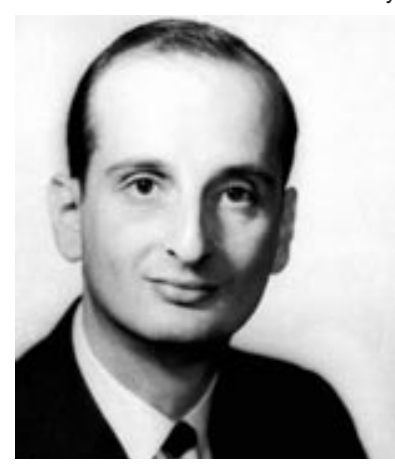

test his theory that cancer cells elaborated a chemical signal that recruited blood vessels. He inserted cancer cells where normally there are no blood vessels-in the corneas of rabbits. Blood vessels began to shoot out from the limbus of the cornea in a direct line towards the cancer cells. Once they reached the tiny tumours, the cancers grew explosively.

One well-known pathologist dismissed his findings as the byproduct of non-specific inflammation. It seemed that he was at a dead end when other researchers reported that uric acid crystals they'd placed in rabbit corneas also triggered blood vessel growth. But Folkman was relentless. According to Robert Cooke, author of Dr Folkman's War: Angiogenesis and the Struggle to Defeat Cancer, at one point Folkman showed a paper he had written to John Enders and asked if he was "giving too much away" in the paper, allowing someone to steal his ideas. Enders told Folkman would fascinate and drive him for the rest of his career: the cancer cells grew into tiny tumours, but they all stopped growing at about $1 \mathrm{~mm}$ in size.

Curious about why the cells would stop growing and thinking that they might have died, Folkman injected the arrested cancer cells from the rabbit thyroid into mice. The cancers grew rapidly. He noted that the mouse tumours had abundant blood vessel growth while there was none in the cultured thyroid tumours. He suspected that the cancer cells in live animals were sending out some sort of chemical signal that recruited the cancer's "own private blood supply."

His military service over, Folkman returned to work as a surgeon at Harvard, becoming, at 34 , the youngest chief of surgery at the Children's Hospital in Boston. When operating Folkman noted that the cancers he held in his hands were "hot and red and bloody." He became more convinced than ever that blood supply was critical to cancers. He began laboratory research at night and weekends to not to worry, that his ideas were "theft-proof" because no one would believe them.

In 1983 Folkman and his colleagues isolated a protein from the urine of cancerous mice that, when placed in a pellet in rabbit cornea, triggered a torrent of blood vessel growth. Folkman immediately began to pursue work to find a substance that could block his newly discovered angiogenic factor, believing that if he could halt blood vessel growth into a cancer, it would be rendered harmless. Eventually he discovered two antiangiogenic molecules that he dubbed angiostatin and endostatin.

Folkman's reputation soared. Researchers took up the cause of angiogenesis. Drug companies raced to be first to develop antiangiogenesis agents. The floodgates broke in 1998, when a story in the New York Times quoted Nobel laureate James Watson as saying that Folkman would cure cancer in two years. Although Watson would later say he was misquoted, the damage was done. Thousands of patients descended on oncologists begging for treatment with angiogenesis inhibitors.
Folkman reminded everyone that the cure he'd found was for mice.

Folkman's reputation as a kindly surgeon never changed. He made himself available at all hours to patients and their families. After he stopped working as a surgeon, he would still respond to over 10 phone calls each night.

As Folkman became a cause célèbre, inflated expectations led to disappointment when clinical trials of antiangiogenic agents in humans proved far less spectacular than they had in mice. To make matters worse, other researchers had trouble replicating Folkman's findings. Some physicians who had referred patients to him said some of his claims were bloated. In a moment that would prove embarrassing to Folkman and two of his colleagues, Harvard University was forced to issue an apology about a paper they published in the New England Journal of Medicine about the efficacy of angiogenesis inhibition in the treatment of large haemangiomas.

Nor was the first commercial application of antiangiogenesis treatment for cancer without pitfalls. Bevacizumab, approved to treat colon cancer, extended the lives of patients a modest five months. And the price was high, both in side effects and cost: patients paid upwards of $\$ 100000$ a year for the drug in 2006. Folkman was not deterred by early modest successes in cancer treatment, saying that many successful treatments take decades to refine.

Author Robert Cooke says Folkman was widely thought to be in line for a Nobel prize. "He had at least four developments, each of which deserved a Nobel. While still a student at Harvard, he developed one of the first implantable pacemakers. He developed the leaky plastics used to make implantable drugs. And he discovered proangiogenic and antiangiogenic agents. Unfortunately, they don't award the Nobel prize posthumously." Moses Judah Folkman, professor of cell biology, Harvard Medical School, and director, vascular biology department, Children's Hospital, Boston (b 1933; q Harvard 1957), died from a heart attack on 14 January 2008.

Jeanne Lenzer

OBITUARIES continue on p 283 


\section{Ivo John Carré}

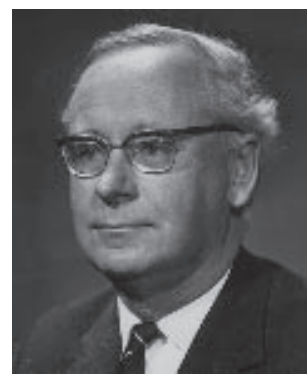

Professor emeritus of child health Queen's University, Belfast (b 1920; q Cambridge/St Thomas's 1944; MD, FRCP, FRCPCH), d 16 December 2007.

Ivo John Carré received his early training in paediatrics in London and Birmingham, and was later a research fellow in Melbourne. In 1956 he became senior lecturer in child health in Belfast, and professor in 1963 , retiring in 1984 . He pioneered clinical studies of hiatus hernia and gastro-oesophageal reflux in children. Ivo travelled widely as lecturer and examiner, being for a time professor of child health in Ibadan, Nigeria. He retired to his 15th century family farmhouse in his native Guernsey, maintaining it himself and researching the Carré family in the Channel Islands and France. He leaves a wife, Pamela; two children; and four grandchildren.

Desmond Creery

\section{David Lionel Gullick}

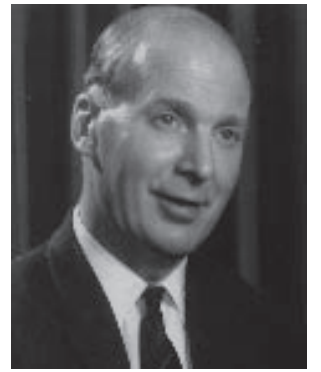

Former deputy secretary BMA (b 1919; q Guy's Hospital, London, 1943), died from chest infection, heart failure, and rheumatoid arthritis on 16 February 2007. A talented rugby player, David Gullick helped to found Stevenage Rugby Club after joining a general practice there, qualifying as a referee. But in the mid-1950s he developed rheumatoid arthritis, and in 1958, when he could no longer continue in general practice, he became medical assistant secretary of the BMA. In 1977 he retired early from his post as deputy secretary of the BMA to become company secretary and executive medical adviser to BUPA. A modest and unassuming man, he reached the semi-final rounds of the "Brain of Britain" contest in 1961. He also helped to inaugurate the Guild of Medical Ringers in 1955, being its first secretary until 1976 and later its president. Predeceased by his wife, Evelyn, he leaves two sons and two grandsons.

John Havard

\section{Angela Isabel Jameson}

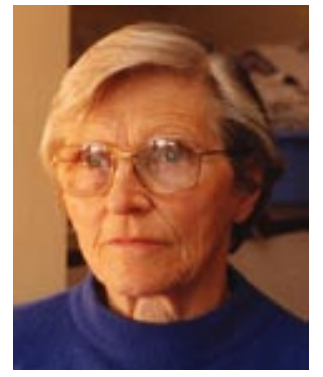

Former general practitioner Bath (b 1923; q London 1947), d 12 November 2007.

Angela Isabel Jameson qualified when it was still difficult for women to enter medicine, showing the singleminded determination that characterised her life. Her husband, Bobby, took over a singlehanded family practice in Bath in 1951, and she looked after the family while being actively involved in the practice, including taking all the telephone calls, boiling syringes in pressure cookers, and arranging talks for the antenatal clinics. In 1968, after refresher courses, Angela became a part time partner in the Batheaston practice, in 1971 joining her husband and his partner as a half time partner until her retirement in 1985. Predeceased by Bobby in 2007 , she leaves four children and 14 grandchildren.

Paul Booth

\section{Harold Frazer Lake}

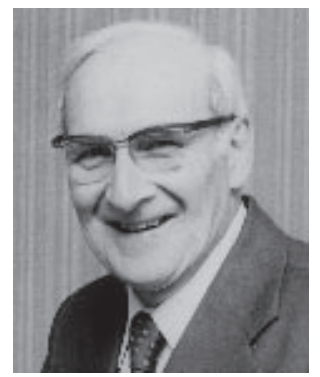

Former consultant ophthalmic surgeon Sunderland Eye Infirmary (b 1924; q Durham 1947; DO, FRCOphth), died from prostate cancer on 31 March 2007. After qualification and house jobs, Harold Frazer Lake did two years of national service in the army (1948-50); he served as a major in the Royal Army Medical Corps (Territorial Army) from 1951 to 1965. In 1961 he was appointed consultant ophthalmologist to Sunderland and South Shields Hospital Groups until his retirement in 1982. He developed a special interest in contact lens practice, and he helped found and was president of the North of England Ophthalmological Society. After retirement, Harold spent three years as sole ophthalmologist to the Sa'ada Province and Northern Territories (population 1 million) in the Yemen Arab Republic.

John Richardson

\section{Elizabeth Geraldine Helen Rhodes (née Morris)}

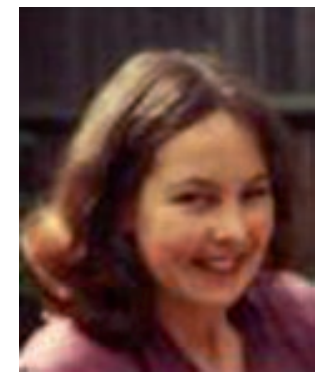

Former consultant haematologist Countess of Chester Hospital Chester (b 1951; q Royal Free Hospital 1971; MD, FRCP, FRCPath), died in an accident at home on 9 September 2007.
Elizabeth Geraldine Helen Rhodes (née Morris) ("Liz") studied arts subjects at A level, entering medical school via the first MB. She trained in haematology initially at the Royal Free and later as part time senior registrar in Birmingham and Liverpool. She was awarded the young investigator award of the British Society of Haematology in 1985 for her research into multiple myeloma, and she focused on haematological malignancy in her clinical work. Family tragedies followed by a stressful work situation led to her early retirement in 2001. She never fully recovered her previous vitality but produced beautiful art. She leaves a husband, Jonathan, and three daughters.

Jonathan Rhodes, Andrew Morris Robert Morris

\section{David Hugh Thomas}

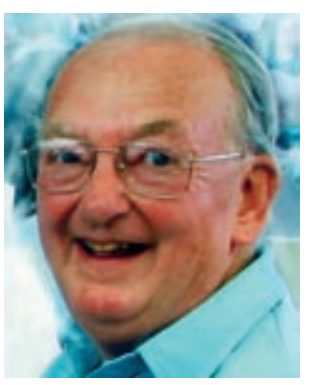

Former general practitioner Whitby (b 1932; q Leeds 1956; DRCOG), died from a stroke on 12 October 2007.

After house jobs, David Hugh Thomas elected for a short service commission in lieu of national service and was posted to Jamaica and British Honduras (Belize). Subsequently he served more than 30 years as a general practitioner in Whitby. As a clinical assistant he promoted obstetric, orthopaedic, and inpatient services at Whitby Community Hospital. Doctor to the Whitby lifeboat and a serving brother of St John Ambulance, David also helped develop the Captain Cook Museum, now located in the house where he first lived, and he researched the diet of the Endeavour's crew. In his teens he was a golfer with a single handicap. He leaves a wife, Joan; three children; and six grandchildren.

Harry Egdell 